\section{Tillage and crop rotation impacts on greenhouse gas fluxes from soil at two long- term agronomic experimental sites in Ohio}

\author{
B. Campbell, L. Chen, C. Dygert, and W. Dick
}

\begin{abstract}
Soils may be a source or sink of greenhouse gases (carbon dioxide [ $\left.\mathrm{CO}_{2}\right]$, nitrous oxide $\left[\mathrm{N}_{2} \mathrm{O}\right]$, and methane $\left.\left[\mathrm{CH}_{4}\right]\right)$ that lead to global warming and climate change. While it is known that greenhouse gases are naturally cycled through soil and are part of the carbon (C) and nitrogen $(\mathrm{N})$ cycles, it is not fully understood what effect crop production practices have on this cycling. Therefore, a study was conducted at the longest, continually maintained no-tillage plots in the world at Wooster (50 years no-till), near Wooster, Ohio, and Hoytville (49 years no-till), near Custar, Ohio, that represent two contrasting Ohio soils. Fluxes of greenhouse gases were measured by gas chromatography (GC) biweekly and following rainfall events greater than $1.2 \mathrm{~cm}$ (0.5 in) during the growing season of the corn (Zea mays L.), starting in July of 2011 until October of 2011, and then from May of 2012 to July of 2012 Samples were obtained at both sites in plots with rotations of corn after corn (CC) and corn after soybean (Glycine max L.) (CS), and when soils were managed using no-tillage (NT) and chisel or minimum conservation tillage (MT). Comparisons statistically significant at the $p$ $<0.10$ level are as follows. For $\mathrm{CO}_{2}$, the $\mathrm{CS}$ rotation yielded lower emissions than the $\mathrm{CC}$ at both sites, due to less biomass cycling. For $\mathrm{N}_{2} \mathrm{O}$, the $\mathrm{CS}$ rotation yielded lower emissions than the CC at both sites due to less total $\mathrm{N}$ fertilizer input in the CS than the CC rotation. The NT system resulted in lower $\mathrm{N}_{2} \mathrm{O}$ emissions than the MT system at Hoytville, but not at Wooster. For $\mathrm{CH}_{4}$, soil in the long-term plots often acted as sinks. Global warming potentials were lower for Hoytville than Wooster and lower for rotation of CS than CC at both Hoytville and Wooster. Overall, after about 50 years, it is evident that the use of no-tillage combined with crop rotations can lead to improved environmental (i.e., greenhouse gas emissions and global warming potential) benefits.
\end{abstract}

Key words: No-tillage—crop rotation—greenhouse gases—methane-nitrous oxidecarbon dioxide

\begin{abstract}
Global climate change, experienced as an increase in the average measured temperature of the earth's near surface air and oceans, is increasingly recognized as a threat to our planet's sustainability (Hsu et al. 2010). Temperature increase is mainly attributed to greenhouse gases accumulating in the atmosphere. Greenhouse gases (GHG), such as water, carbon dioxide $\left(\mathrm{CO}_{2}\right)$, nitrous oxide $\left(\mathrm{N}_{2} \mathrm{O}\right)$, and methane $\left(\mathrm{CH}_{4}\right)$ absorb solar energy and trap it so that it cannot be emitted back into the atmosphere, thus raising the temperature of the earth's atmosphere (Hsu et al. 2010; Pant 2009). Due to the overall size and the nature of agricultural activities, agriculture now supplies from 3\%
\end{abstract}

spheric $\mathrm{CO}_{2}$ levels unless it takes $\mathrm{C}$ stored in soil for thousands of years and converts it to $\mathrm{CO}_{2}$. When a soil is at equilibrium in regards to soil organic $\mathrm{C}$ concentrations, the soil is neither a source nor sink of $\mathrm{CO}_{2}$.

Nitrous oxide is mainly produced through denitrification processes in the soil. Denitrifying bacteria are most commonly facultative anaerobes and can survive under aerobic conditions in soil as well as where $\mathrm{O}_{2}$ is devoid. Some research has shown that conservation tillage, especially no-tillage, results in greater amounts of $\mathrm{N}_{2} \mathrm{O}$ emissions than do intensive tillage systems (Flessa et al. 2002; Grant et al. 2004; Halvorson et al. 2006; Koga et al. 2006). This is attributed to the residue left by conservation tillage keeping the soil wetter and providing energy to the denitrifying microorganisms. However, other research indicates that no-tillage produces less $\mathrm{N}_{2} \mathrm{O}$ than does conventional tillage (i.e., moldboard plow or chisel tillage) (Omonode et al. 2011). This was attributed to conventional tillage causing more soil organic C decomposition due to higher levels of soil-residue mixing and higher soil temperatures. No-tillage (NT) or chisel or minimum conservation tillage (MT) can also maintain higher soil moisture levels and surface soil organic matter than where more intensive tillage practices are used. These conditions can lead to both increased nitrate $\left(\mathrm{NO}_{3}^{-}\right)$levels and more anaerobic microsites that, in turn, lead to increase $\mathrm{N}_{2} \mathrm{O}$ production.

Soils can be a source for $\mathrm{CH}_{4}$ with most production due to methanogenic bacteria in flooded soils such as those in rice paddies (Cole et al. 1997; Ishizuka et al. 2005). Soils can also be sinks of $\mathrm{CH}_{4}$ when methanotrophic bacteria take up $\mathrm{CH}_{4}$ to oxidize it for energy production (Adhya et al. 1998). There is evidence that tillage reduces this oxidation in soils leading to less $\mathrm{CH}_{4}$ removal (Adhya et al. 1998). If this is the case, NT should be more beneficial because it can increase $\mathrm{CH}_{4}$ oxidation and thus serve as a sink for atmospheric $\mathrm{CH}_{4}$. This was observed for a no-tillage chronosequence in Ohio (Jacinthe et al. 2014).

Although research has been performed on the effects of tillage on GHG emissions

Brittany Campbell is a graduate student, Liming Chen and Clay Dygert are research associates, and Warren Dick is a professor at The Ohio State University in the Ohio Agricultural Research and Development Center in Wooster, Ohio. 
(MacKenzie et al. 1997; Omonode et al. 2011; Venterea et al. 2005; Jacinthe and Dick 1997), most has focused on comparing traditional plow tillage with conservation tillage. As traditional plow tillage is becoming less used in Ohio and elsewhere in North America, a comparison of the now more common conservation tillage practices, such as chisel tillage with no-tillage is considered more relevant.

Crop rotation is another production variable that impacts GHG emissions. With the advent of greater use of corn (Zea mays L.) as a feedstock for biofuels production as well as the traditional uses as an animal feed and other end uses, corn is increasingly being continuously grown without rotation with other crops. This results in more total fertilizer input to soil. Also, crop rotation effects on GHG emissions are normally limited to looking at the difference between different crops rather than emissions from the same crop in a rotation, e.g., emissions from a cornfield where the previous year's crop was corn in comparison to when the previous year's crop was soybean (Glycine max L.) or other crops.

Soil properties, such as texture, are known to affect biological processes like $\mathrm{N}_{2} \mathrm{O}$ production. However, texture was not found to significantly affect $\mathrm{N}_{2} \mathrm{O}$ emissions during the wheat-growing season from 18 Chinese paddy soils (Huang et al. 2002). In contrast, Jarecki et al. (2008) found that cumulative $\mathrm{N}_{2} \mathrm{O}$ emissions were greater from a sandy loam soil than from a clay soil. The authors speculated it was due to the higher cation exchange capacity (CEC) in the clay soil reducing nitrogen $(\mathrm{N})$ availability through increased adsorption of $\mathrm{NH}_{4}$. Similarly, a loam soil was found to emit more of the applied fertilizer as $\mathrm{N}_{2} \mathrm{O}$ than did a clay soil (Weitz et al. 2001).

In this study, we evaluated the effects of crop rotation and tillage on GHG fluxes from two contrasting soils in Ohio under similar climactic situations.

\section{Materials and Methods}

Site Characteristics. Two long-term experimental sites in Ohio were used for this research. The overall soil and terrain properties of the Wooster and Hoytville sites have been previously described (Dick et al. 1986a; Dick et al. 1986b; Dick et al. 1991). However, it is important to note that these soils are contrasting in texture with the Wooster site soil being a silt loam (14\% clay) and the Hoytville site soil being a silty clay loam ( $31 \%$ clay). While three tillage treatments (NT, MT, and plow-tillage [PT]) and three crop rotations (continuous corn after corn [CC], corn after soybean [CS], and corn after oats (Avena sativa L.) and meadow hay [COM]) were present on the fields; only soil from plots of the NT and MT treatments and the CC and CS crop rotations were sampled.

Crop rotations at both sites consist of a $\mathrm{CC}$ rotation and a CS rotation. The corn hybrid and soybean varieties grown differed over the years and were selected to maximize yield on each soil type. The plots were set up in a completely randomized block design with three replicates. Every crop was grown each year so that every year there was a corn crop following either a corn crop or a soybean crop. Temperature and precipitation data at each site are provided in figure 1.

Tillage operations were either MT (i.e., chisel plow) or NT. The chisel plow was equipped with 15 slightly curved shanks 13 $\mathrm{cm}$ (5 in) in width and pulled through the soil to a depth of 15 to $20 \mathrm{~cm}$ (6 to 8 in). This method prepares the seedbed for planting while leaving much of the residues on the soil surface. The amount of residue on the soil surface exceeded 30\% cover (as deemed necessary to be conservation tillage), but by the end of the growing season the residue had mostly disappeared from the soil surface. Tillage was conducted from opposite directions every other year at both Wooster and Hoytville to avoid creating any rills in the soil and reduce tillage erosion. A tandem disc (3 m [10 ft] width) or field cultivator $(4.5 \mathrm{~m}$ [15 ft] width) was used to prepare the final seedbed prior to planting. Primary tillage (i.e., chisel tillage) occurred in the fall at the Hoytville site, with secondary tillage in the spring. For the Wooster site, both primary and secondary tillage occurred in the spring. Corn was planted on June 4, 2011, and May 6, 2012, at the Wooster site, and June 6, 2011, and April 24, 2012, at the Hoytville site. Soil characteristics for the Wooster and Hoytville sites are summarized in table 1 .

Nitrogen was applied as liquid ureaammonium nitrate at a rate of $202 \mathrm{~kg} \mathrm{~N} \mathrm{ha}^{-1}$ $\left(180 \mathrm{lb} \mathrm{N} \mathrm{ac}^{-1}\right)$ at Wooster and $224 \mathrm{~kg} \mathrm{~N}$ $\mathrm{ha}^{-1}\left(200 \mathrm{lb} \mathrm{N} \mathrm{ac}^{-1}\right)$ at Hoytville for the CC plots and $168 \mathrm{~kg} \mathrm{~N} \mathrm{ha}^{-1}\left(150 \mathrm{lbs} \mathrm{N} \mathrm{ac}^{-1}\right)$ at Wooster and $190 \mathrm{~kg} \mathrm{~N} \mathrm{ha}^{-1}\left(170 \mathrm{lb} \mathrm{N} \mathrm{ac}{ }^{-1}\right.$ ) at Hoytville only to the corn plots of the CS rotation. Application dates for $\mathrm{N}$ fertilizer were June 29, 2011, and June 11, 2012, at the Wooster site, and June 21, 2011, and June 6, 2012, at the Hoytville site.

Experimental Setup. Gas samples were collected from the individual plots at each site. Gas collection chambers were constructed of PVC pipe with an inner diameter of $30 \mathrm{~cm}$ (11.8 in), a height of $20.5 \mathrm{~cm}(8$ in) above the soil, and a thickness of $1 \mathrm{~cm}$ (0.4 in) (Campbell 2012). The bottom edge of the chamber has an approximately $2.5 \mathrm{~cm}$ (1 in) beveled edge with the sharp edge on the inside of the PVC wall. This allows easier insertion into the soil with less compaction. The top edge of the chamber is lined with a gas resistant rubber gasket to help create a tighter seal with the lid. The chamber lid consists of a solid piece of PVC $1 \mathrm{~cm}$ (0.4 in) thick and $30 \mathrm{~cm}$ (11.8 in) in diameter with the same rubber sealing along the edge. In the center of the lid, a $1 \mathrm{~cm}(0.4 \mathrm{in})$ diameter grey butyl rubber septum is placed. A syringe is pushed through the septum to gather air samples from within the sealed chamber.

Gas collection chambers were placed approximately 2 to $3 \mathrm{~m}$ (6.5 to $9.8 \mathrm{ft}$ ) from the edge of the plot into the field in late June of 2011. Two chambers were used per plot, placed in between the center rows of each plot. The chambers were not removed once they were placed in the ground until the last sampling right before harvesting of the corn crop in late November. In 2012, chambers were again placed approximately 2 to $3 \mathrm{~m}$ (6.5 to $9.8 \mathrm{ft}$ ) from the edge of the plot into the field. Two chambers were used per plot, but this time one was placed in the center of the row and one was placed within the corn row. This was done to assess whether chamber placement affected the gas fluxes measured, but comparisons of flux data from in the row or between the rows showed no statistical differences (Campbell 2012). Thus, the effect of chamber placement was ignored when making calculations for the 2012 data. The chambers were placed in early May and sampled until mid-July when the drought conditions of 2012 resulted in almost no GHG emissions.

Chambers were sampled biweekly, and additional samplings were conducted following any rainfall event greater than $1.2 \mathrm{~cm}(0.5$ in) total. Plants within the chambers were removed throughout the sampling period so that fluxes represent only those from soil. Initial samples were taken after the lid was sealed over the soil, i.e., at time zero. Samples 


\section{Figure 1}

(a) Temperature (monthly average) and (b) precipitation (monthly total) data for the Wooster and Hoytville sites during the time of gas flux measurements.

(a)

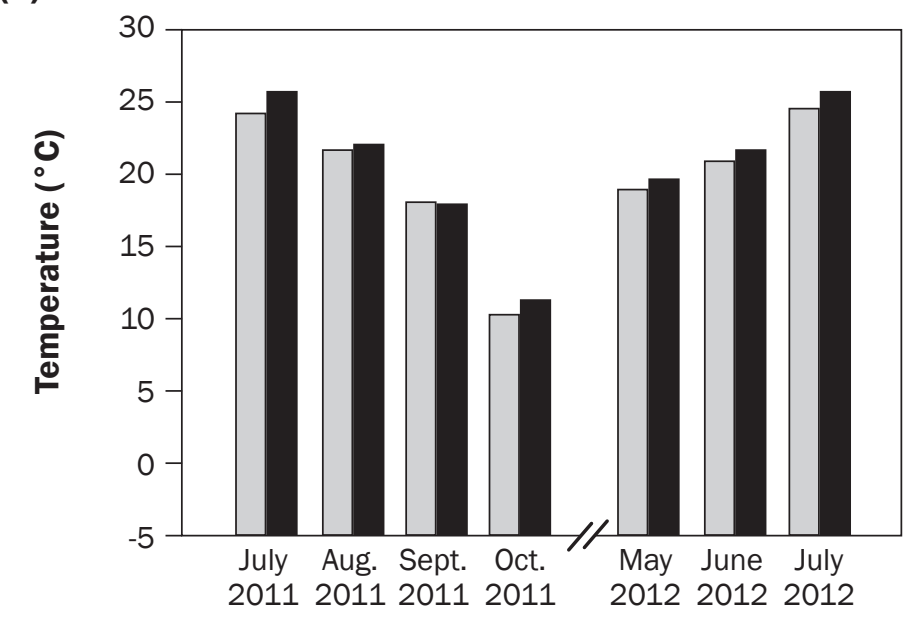

(b)

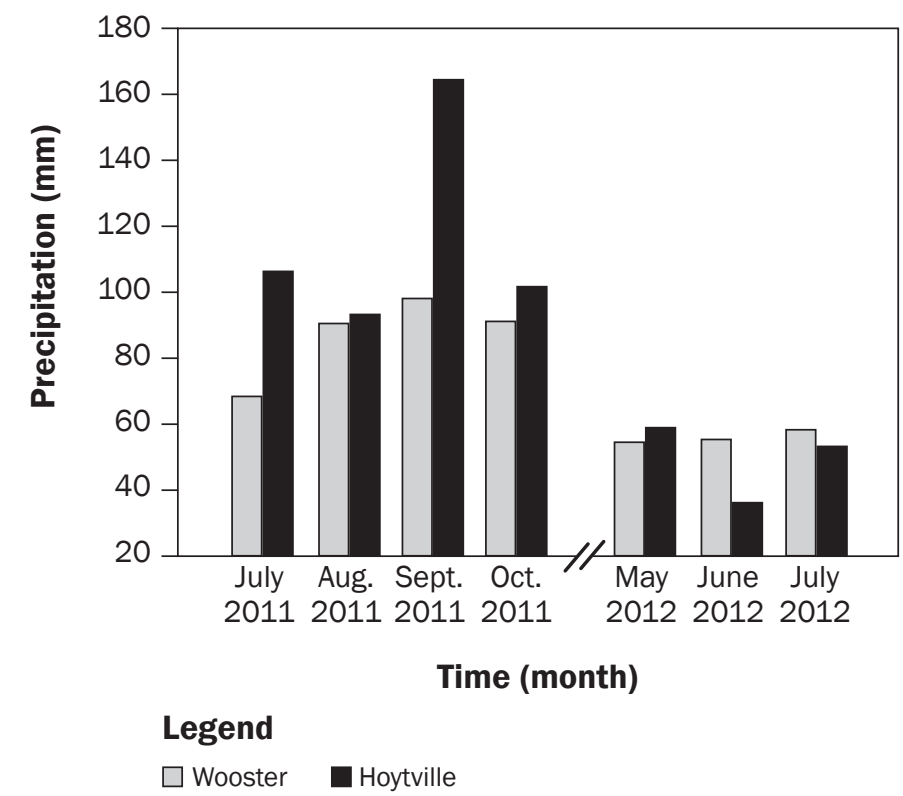

were then taken from the chamber 30 and 60 minutes later in the same manner. After sampling was completed, the lids were removed and the soil in the chamber was exposed to natural weather conditions. Each gas sample collected was placed into separate $15 \mathrm{~mL}(0.3$ in $^{3}$ ) labeled glass vials that were crimp-sealed with gray butyl rubber septa used as stoppers. Prior to sampling, the vials were evacuated to a pressure of $<0.06 \mathrm{kPa}$.
Gas Sample Analysis. Concentrations of $\mathrm{CO}_{2}, \mathrm{~N}_{2} \mathrm{O}$, and $\mathrm{CH}_{4}$ were determined using a Varian CP3800 gas chromatograph (Palo Alto, California). The gas chromatograph was equipped with thermal conductivity (TCD), flame ionization (FID), and electron capture $\left(\mathrm{ECD},{ }^{63} \mathrm{Ni}\right.$ ) detectors for analyses of $\mathrm{CO}_{2}$, $\mathrm{CH}_{4}$, and $\mathrm{N}_{2} \mathrm{O}$, respectively. The carrier gas was ultra-high purity (UHP) He (Helium) set at a $20 \mathrm{~mL} \mathrm{~min}{ }^{-1}$ rate for the analysis of $\mathrm{CO}_{2}, \mathrm{CH}_{4}$, and UHP $\mathrm{N}_{2}$ set at a $60 \mathrm{~mL}$ $\mathrm{min}^{-1}$ rate for analysis of $\mathrm{N}_{2} \mathrm{O}$. The oven temperature was set to $90^{\circ} \mathrm{C}\left(194^{\circ} \mathrm{F}\right)$, detector temperatures were set to $150^{\circ} \mathrm{C}\left(302^{\circ} \mathrm{F}\right)$ for TCD and FID, and $300^{\circ} \mathrm{C}\left(572^{\circ} \mathrm{F}\right)$ for ECD. A precolumn of $0.3 \mathrm{~m}$ (0.9 in) length and $2 \mathrm{~mm}$ (0.07 in) inner diameter was placed before the analytical column of $1.8 \mathrm{~m}$ (5.9 $\mathrm{ft}$ ) length and $2 \mathrm{~mm}$ (0.07 in) inner diameter. The columns were packed with Porapak $\mathrm{Q}$ of 80 to 100 mesh. The analytical column was baked at $150^{\circ} \mathrm{C}\left(302^{\circ} \mathrm{F}\right)$ for 10 minutes after every 20 samples that were run on the instrument. For calibration, gas standards from Altech (Deerfield, Illinois) and Air Liquide (Troy, Michigan) were run. Standards concentrations ranged from 100 to $1000 \mu \mathrm{L}$ $\mathrm{CO}_{2} \mathrm{~L}^{-1}, 1.7$ to $100 \mu \mathrm{L} \mathrm{CH}_{4} \mathrm{~L}^{-1}$, and 0.1 to $1 \mu \mathrm{L} \mathrm{N} \mathrm{N}_{2} \mathrm{~L}^{-1}$.

Concentrations for each gas were determined in ppm from the gas chromatograph. From here, concentrations were turned into flux values of $\mathrm{g} \mathrm{CO}_{2}-\mathrm{C} \mathrm{m}^{2} \mathrm{~d}^{-1}, \mathrm{mg} \mathrm{CH}_{4}-\mathrm{C}$ $\mathrm{m}^{2} \mathrm{~d}^{-1}$, and $\mathrm{mg} \mathrm{N}_{2} \mathrm{O}-\mathrm{N} \mathrm{m}^{2} \mathrm{~d}^{-1}$ using the following relationship:

$F=\frac{\Delta C}{\Delta \mathrm{t}} \times \frac{V}{A} \times k$,

where $\Delta \mathrm{C} / \Delta \mathrm{t}$ equals the rate of gas accumulation inside of the chamber in $\mathrm{ppm} \mathrm{min}^{-1}$, $\mathrm{V}$ equals the volume of the chamber in $\mathrm{L}, \mathrm{A}$ equals the area of the chamber in $\mathrm{cm}^{2}$, and $\mathrm{k}$ equals the conversion factors needed for time $\left(1,440 \operatorname{min~}^{-1}\right)$ and volume $\left(\mathrm{g} \mathrm{L}^{-1}\right.$ gas at STP).

The global warming potential (GWP) of each site was also determined using 100-year radiative forcing values, as determined by the

\section{Table 1}

Surface soil properties from the Wooster (o to $3 \mathrm{~cm}$ ) and Hoytville (o to $5 \mathrm{~cm}$ ) sites collected in 2005 .

\begin{tabular}{lllllllll}
\hline Site & Type & pH & $\begin{array}{l}\text { Bulk density } \\
\left.\mathbf{( M g ~ m}^{-3}\right)\end{array}$ & Total carbon (\%) & Total nitrogen (\%) & Sand (\%) & Silt (\%) & Clay (\%) \\
\hline Wooster & Silt loam & 5.5 & 1.49 & 3.47 & 0.317 & 13.8 & 72.5 \\
Hoytville & Clay & 6.0 & 1.01 & 3.88 & 0.333 & 13.7 & 52.8 & 30.6
\end{tabular}


Intergovernmental Panel on Climate Change (IPCC) (Parry et al. 2007). The forcing values were 1 for $\mathrm{CO}_{2}, 25$ for $\mathrm{CH}_{4}$, and 298 for $\mathrm{N}_{2} \mathrm{O}$. This means that $\mathrm{CH}_{4}$ is 25 times more effective at trapping radiative emissions in the atmosphere than $\mathrm{CO}_{2}$ over a 100 year timespan. All of the greenhouse gas fluxes were converted to $\mathrm{CO}_{2}$ equivalents in calculating the global warming value for each site.

Data Analysis. A repeated measures general linear model (GLM) analysis of variance test (ANOVA) with Tukey's multiple comparisons was performed at the $\alpha=0.1$ significance level using MiniTab 15 software. A GLM-ANOVA procedure was used since it works with unbalanced factors and fixed and/or random factors, such as those used in this analysis.

\section{Results and Discussion}

Effects of Crop Rotation on Greenhouse Gas Fluxes. Greenhouse gas fluxes as affected by crop rotation at Wooster are presented in figure 2. For $\mathrm{CO}_{2}$ and $\mathrm{N}_{2} \mathrm{O}$ emissions, there were significant differences between the CC and the CS rotation (table 2), and the $\mathrm{CC}$ rotation resulted in higher emissions than did the CS rotation (figure $2 \mathrm{a}$ and $2 \mathrm{c}$ ). The emission rates of $\mathrm{N}_{2} \mathrm{O}$ were similar to the results reported by Venterea et al. (2005) and Parkin and Kaspar (2006). The $\mathrm{CH}_{4}$ gas flux analysis revealed there was no significant difference between the CC and the CS rotation, while interactions of crop rotation with tillage and date were significant (table 2 ). The interaction of date and crop rotation showed that $\mathrm{CH}_{4}$ emissions under the $\mathrm{CC}$ rotation were higher than the emissions under the CS rotation on some dates but reversed on other sample collecting dates (figure $2 \mathrm{~b}$ ).

For $\mathrm{N}_{2} \mathrm{O}$ emissions, the total amount of $\mathrm{N}$ fertilizer applied to the CC plots totals more than that applied to the CS plots due to fertilizer applied every year for the CC rotation plots but only every other year for the CS rotation plots. This explains the higher $\mathrm{N}_{2} \mathrm{O}$ emissions from the CC plots compared to the CS plots. The greater amount of residue also provides an energy (electron) source for denitrifiers in the soil as well as maintaining more water in the soil profile (Alvarez and Steinbach 2009). Both of these factors lead to increased $\mathrm{N}_{2} \mathrm{O}$ emissions. Flessa et al. (2002) found that the greater the coverage of residue, the larger the emissions of $\mathrm{N}_{2} \mathrm{O}$ from the soil. The interaction of crop rotation with date was also significant for $\mathrm{N}_{2} \mathrm{O}$ emissions (table 2). On July

\section{Figure 2}

Greenhouse gas fluxes as affected by crop rotation from the Wooster site. The * shows a difference between corn following corn and corn following soybean at $p \leq 0.10$ at specific sample dates.

(a)

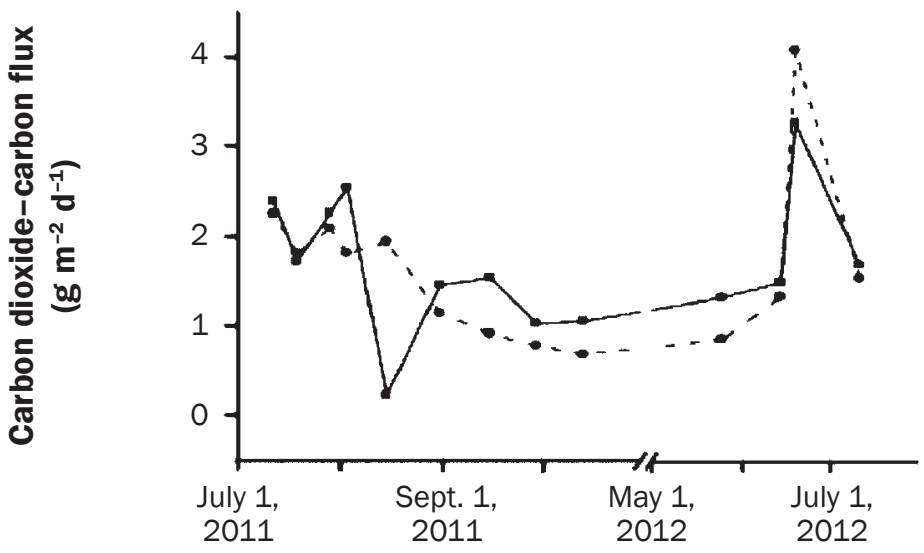

Date sampled

(b)

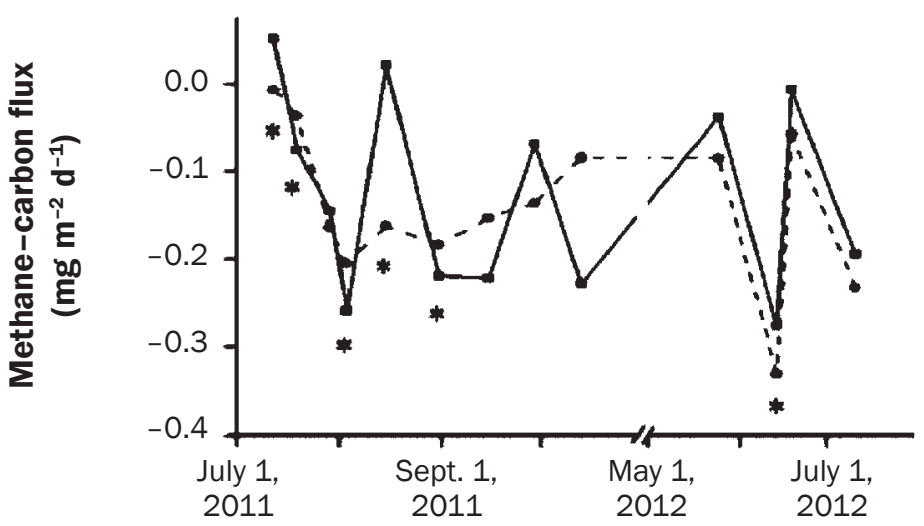

Date sampled

(c)

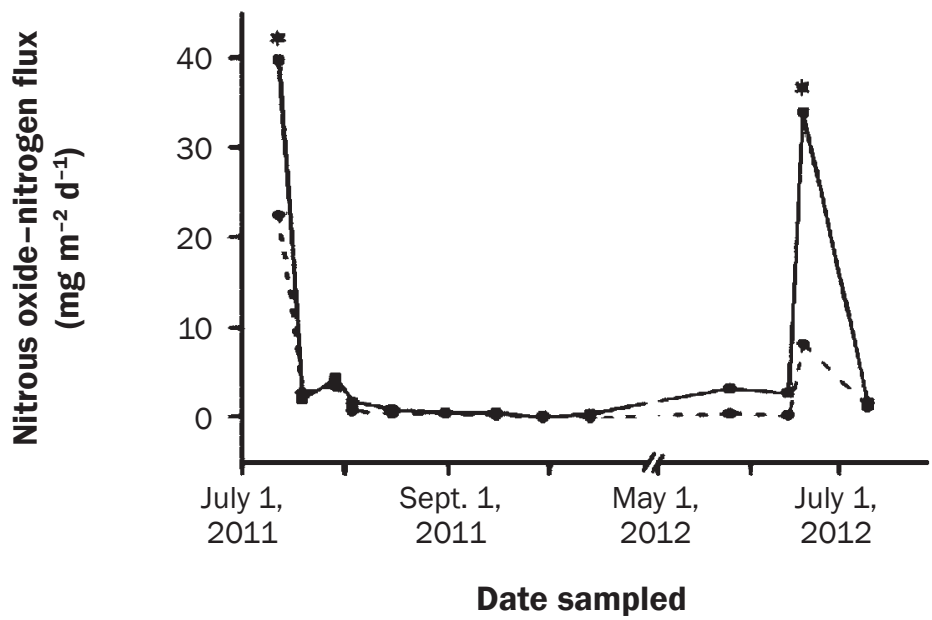

Legend

$\rightarrow$ Corn after corn $\quad$ - $\quad$ - Corn after soybean 
Table 2

Analysis of variance (ANOVA) for carbon dioxide $\left(\mathrm{CO}_{2}\right)$, methane $\left(\mathrm{CH}_{4}\right)$, and nitrous oxide $\left(\mathrm{N}_{2} \mathrm{O}\right)$ fluxes from the Wooster site.

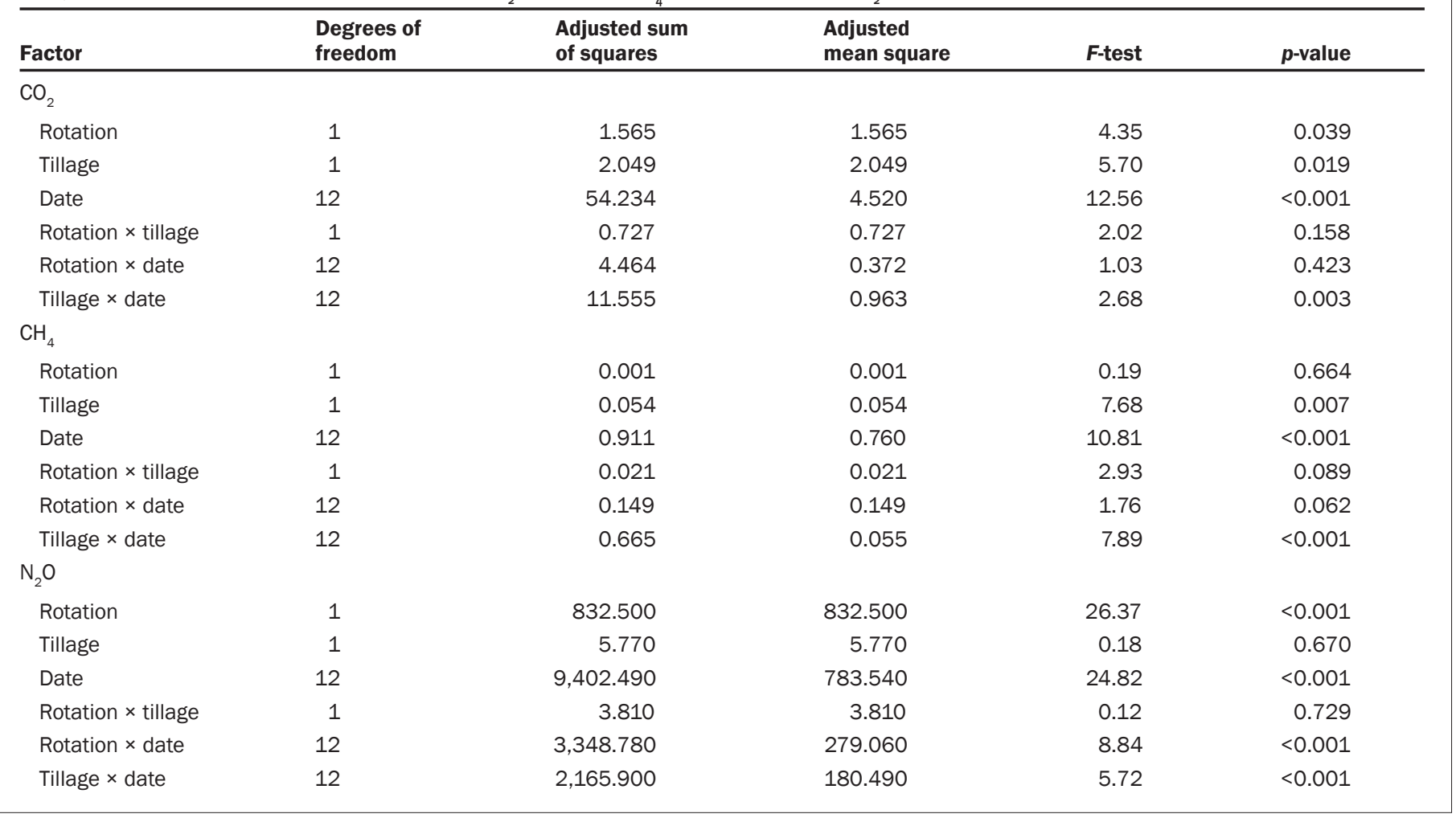

12, 2011, and June 19, 2012, $\mathrm{N}_{2} \mathrm{O}$ emissions for the CC were higher than the $\mathrm{N}_{2} \mathrm{O}$ emissions from the CS (figure 2c). Both of these dates released higher emissions than any other sampling date for either CC or CS. It should be noted that both of these dates were sampled following rainfall and were also about one month following fertilizer application.

Fertilizers, especially $\mathrm{N}$ fertilizers, are known to influence $\mathrm{N}_{2} \mathrm{O}$ emissions when applied at different rates and types (Bouwman 1996; MacKenzie et al. 1997; Venterea et al. 2005). For example, $\mathrm{NO}_{3}^{-}$from fertilizers or after nitrification of ammonium-based fertilizers become the substrate for denitrification reactions. This is one reason for the large spike seen in the $\mathrm{N}_{2} \mathrm{O}$ emissions after $\mathrm{N}$ fertilizer additions to soil. Molodovskaya et al. (2012) also reported episodic behavior of intermittent, short-duration but high intensity peak fluxes of $\mathrm{N}_{2} \mathrm{O}-\mathrm{N}$ emissions. Fertilizer that is applied in the months prior to sampling is converted to $\mathrm{NO}_{3}^{-}$, and when the soil or microsites within the soil become saturated following rainfall, denitrification occurs. Nitrates are also produced when organic matter goes through the process of mineralization to release $\mathrm{NH}_{4}$, followed by nitrification. In the early spring, when there is not yet a growing crop to take up the
$\mathrm{NO}_{3}{ }^{-}$and when soils tend to be wetter, the potential for $\mathrm{N}_{2} \mathrm{O}$ production is high, and this was seen in our data.

Effects of Tillage on Greenhouse Gas Fluxes. Greenhouse gas fluxes as affected by tillage from Wooster are presented in figure 3. For $\mathrm{CO}_{2}$ and $\mathrm{CH}_{4}$ fluxes, there were significant differences between the MT and the NT (table 2). The interaction of tillage with date was significant for $\mathrm{CO}_{2}, \mathrm{CH}_{4}$, and $\mathrm{N}_{2} \mathrm{O}$. For $\mathrm{CO}_{2}$, the emissions for $\mathrm{MT}$ were larger than emissions for NT on August 15, 2011 (figure 3a). The lower emissions of $\mathrm{CO}_{2}$ coming from the NT plots suggest that less $\mathrm{C}$ was being lost from soil, and $\mathrm{C}$ sequestration was occurring as was noted by Kumar et al. (2012). In contrast, as the chisel plow runs through the soil it breaks up soil aggregates. The soil aggregates contain trapped $\mathrm{C}$ and nutrients that were previously unavailable to the atmosphere or microorganisms for decomposition. The newly exposed soil organic $\mathrm{C}$ is also oxidized leading to increased $\mathrm{CO}_{2}$ emissions from the $\mathrm{MT}$ site and less or no $\mathrm{C}$ sequestration compared to NT.

For $\mathrm{CH}_{4}$, soil generally acted as a sink and removed $\mathrm{CH}_{4}$ from the atmosphere above the soil (figure $3 \mathrm{~b}$ ). This is the reason for the mostly negative flux values. The NT soil was less effective as a sink for $\mathrm{CH}_{4}$ than MT on July 19, 2011, and June 14, 2012. On most other dates the reverse was true. Bronson and Mosier (1994) found that as the amount of mineral $\mathrm{N}$ (i.e., $\mathrm{NH}_{4}$ ) in the soil was increased, the oxidation of $\mathrm{CH}_{4}$ was inhibited and more could be emitted to the atmosphere. Thus the amount of $\mathrm{CH}_{4}$ emitted may be a reflection of the mineral $\mathrm{N}$ status, especially $\mathrm{NH}_{4}$, in the soil under MT or NT at various times of the year. Work by Jacinthe et al. (2014) has shown that the longer a soil is under NT, the more it acts as a sink for $\mathrm{CH}_{4}$. There was also an interaction between tillage and rotation for $\mathrm{CH}_{4}$. No-tillage soil was a more effective sink for $\mathrm{CH}_{4}$ under the $\mathrm{CC}$ rotation, while the opposite was true for the CS rotation.

For $\mathrm{N}_{2} \mathrm{O}$ emissions to occur from soil, three things are needed: (1) a population of denitrifying microorganisms under anaerobic conditions; (2) a source of energy that is generally supplied by soluble organic $\mathrm{C}$; and (3) a supply of $\mathrm{NO}_{3}^{-}$. In this study, the $\mathrm{N}_{2} \mathrm{O}$ emission for $\mathrm{NT}$ was higher than $\mathrm{N}_{2} \mathrm{O}$ emission for MT on July 12, 2011, while the emission for MT was higher than the emission for NT on June, 19, 2012. Both of these dates released higher emissions than any other sampling date for either NT or MT. As previously noted, samples obtained 
Figure 3

Greenhouse gas fluxes as affected by tillage from the Wooster site. The * shows a difference between chisel tillage and no-tillage at $p \leq 0.10$ at specific sample dates.

(a)

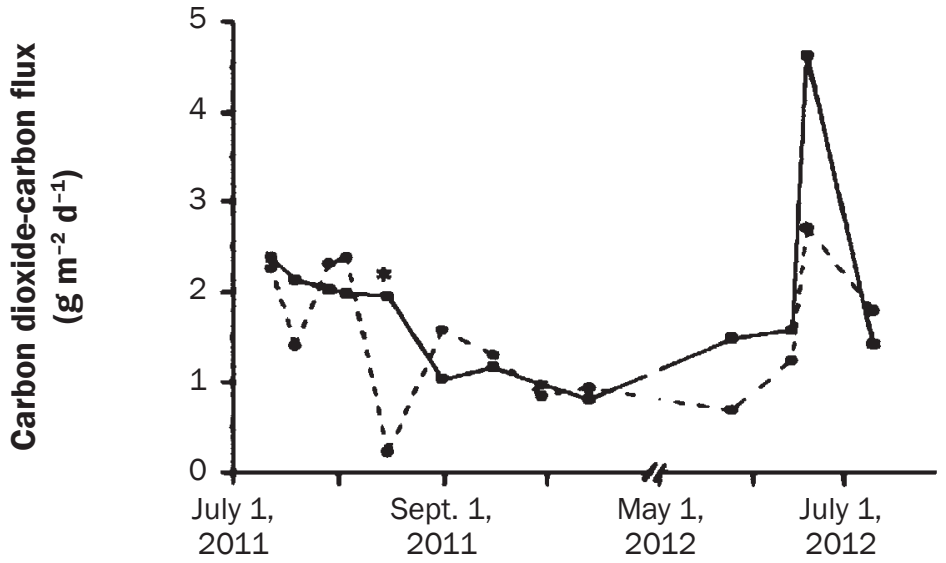

Date sampled

(b)

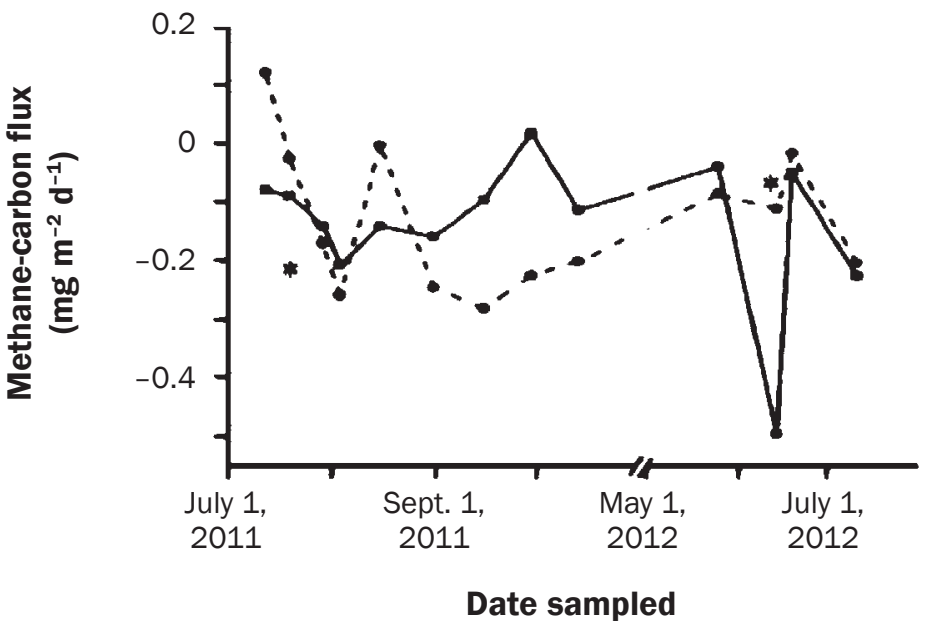

(c)

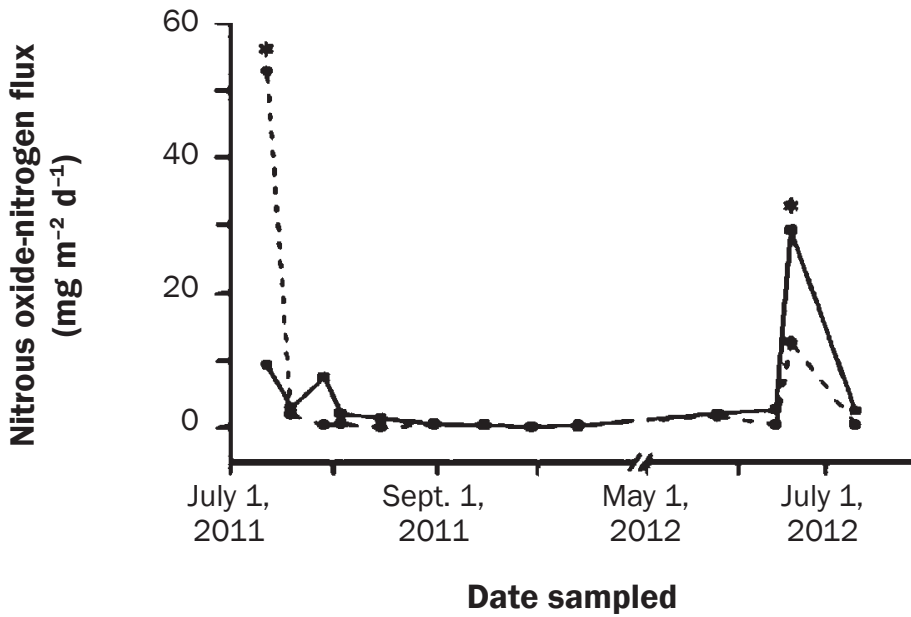

Legend

ـ Chisel or minimum conservation tillage

- - No-tillage on these dates followed rainfall events and were also about one month following fertilizer application.

Effects of Crop Rotation on Greenhouse Gas Fluxes. Greenhouse gas fluxes as affected by crop rotation from Hoytville are presented in figure 4. For $\mathrm{CO}_{2}$ and $\mathrm{N}_{2} \mathrm{O}$ emissions, there were significant differences between the CC and the CS rotations (table 3 ), and the CC rotation yielded higher emissions than did the CS rotation (figure $4 \mathrm{a}$ and 4c). The CC rotation emitted around $0.4 \mathrm{~g}$ $\mathrm{CO}_{2}-\mathrm{C} \mathrm{m}^{-2} \mathrm{~d}^{-1}\left(3.6 \mathrm{lb} \mathrm{CO}_{2}-\mathrm{C} \mathrm{ac}^{-1}\right.$ day $\left.^{-1}\right)$ on average with a max of $1.6 \mathrm{~g} \mathrm{CO}_{2}-\mathrm{C} \mathrm{m}^{-2} \mathrm{~d}^{-1}$ (14 $\mathrm{lb} \mathrm{CO}_{2}-\mathrm{C} \mathrm{ac}^{-1}$ day $^{-1}$ ) while the CS rotation emitted around $0.3 \mathrm{~g} \mathrm{CO}_{2}-\mathrm{C} \mathrm{m}^{-2} \mathrm{~d}^{-1}$ (2.7 $\mathrm{lb} \mathrm{CO}_{2}-\mathrm{C} \mathrm{ac}^{-1}$ day $^{-1}$ ) on average with a max of $1 \mathrm{~g} \mathrm{CO}_{2}-\mathrm{C} \mathrm{m}^{-2} \mathrm{~d}^{-1}\left(8.9 \mathrm{lb} \mathrm{CO}_{2}-\mathrm{C}\right.$ $\mathrm{ac}^{-1}$ day $\left.^{-1}\right)$. This observation can be explained by the fact that the amount of residue produced by the CC rotation is greater than for the CS rotation. Soybeans produce much less residue than corn, and the CS rotation only has corn growing in the field every other year. The $\mathrm{C}$ in the residue is thus emitted as $\mathrm{CO}_{2}$ at a higher rate for the CC plots than the CS plots. Similarly, as was observed at the Wooster site, the CC rotation had higher $\mathrm{N}_{2} \mathrm{O}$ emissions than the CS rotation due to greater total fertilizer $\mathrm{N}$ input. The emissions were highly episodic similar to what was reported for the Wooster soil.

Effects of Tillage on Greenhouse Gas Fluxes. Greenhouse gas fluxes as affected by tillage from Hoytville are presented in figure 5. For $\mathrm{CO}_{2}$ and $\mathrm{N}_{2} \mathrm{O}$ emissions, there were significant differences between the MT and the NT (table 3). The interaction of tillage with date was also significant for $\mathrm{CO}_{2}$ and $\mathrm{N}_{2} \mathrm{O}$. For $\mathrm{CO}_{2}$, the emissions for NT were larger than emissions for MT on July 22, 2011, and September 15, 2011 (figures 5a and $5 \mathrm{c}$ ). For $\mathrm{N}_{2} \mathrm{O}$, the emission for $\mathrm{MT}$ was higher than for NT on July 22, 2011. This date released higher emissions than any other sampling date for either NT or MT. This is approximately one month following fertilizer applications and following rainfall. For $\mathrm{N}_{2} \mathrm{O}$, the interaction of crop rotation with tillage was significant (table 3). The MT treatment under the CC rotation emitted higher concentrations of $\mathrm{N}_{2} \mathrm{O}$ compared with any other treatment (figure 6). The incorporation of the $\mathrm{CC}$ residue on the $\mathrm{MT}$ plots makes $\mathrm{C}$ more readily available to denitrifiers in the soil to use for energy. When fertilizer $\mathrm{N}$ is added, the availability of $\mathrm{C}$ energy, $\mathrm{NO}_{3}^{-}$, and 


\section{Figure 4}

Greenhouse gas fluxes as affected by crop rotation from the Hoytville site. There were no significant differences between rotations at specific sample dates.

(a)

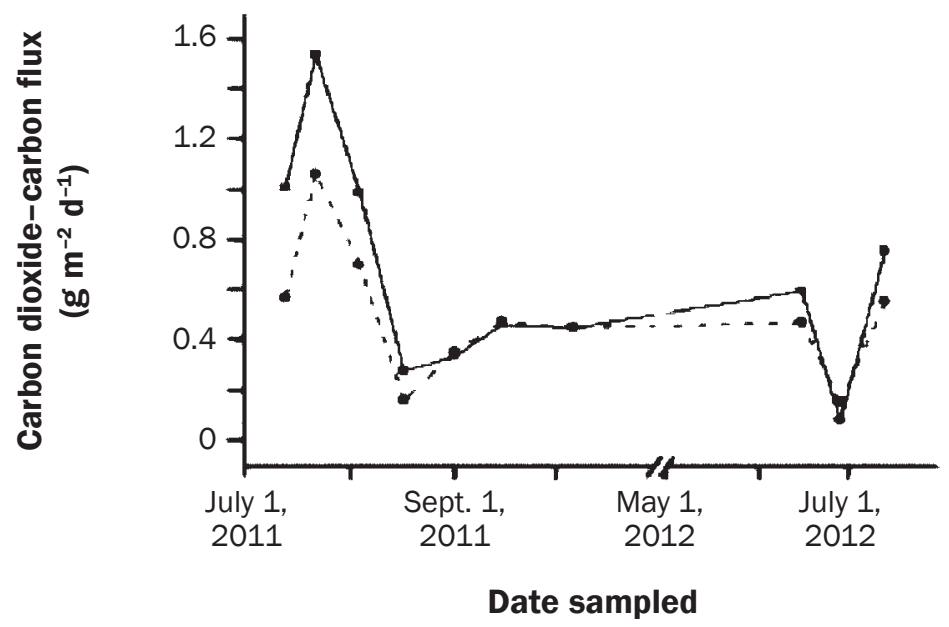

(b)

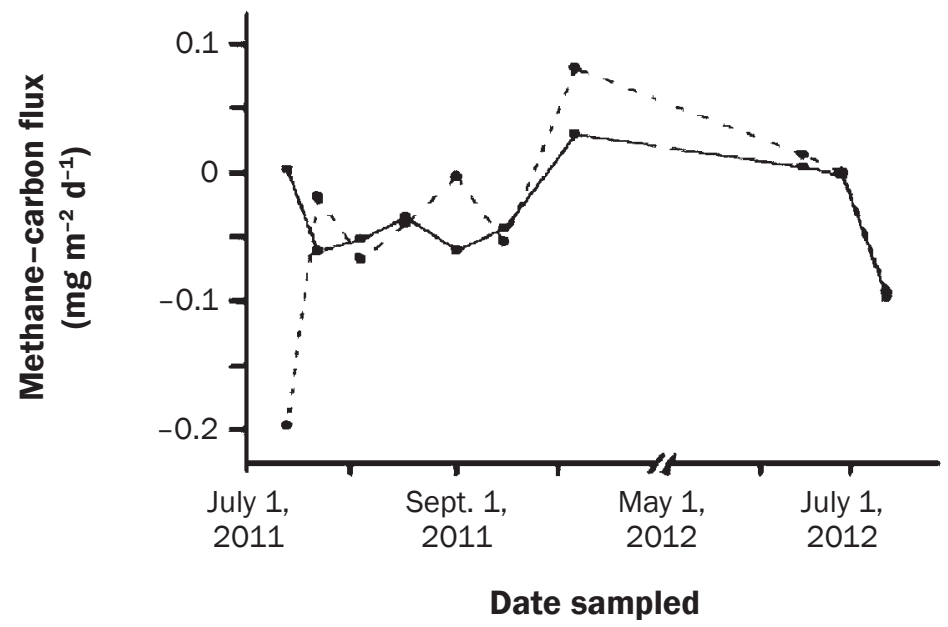

(c)

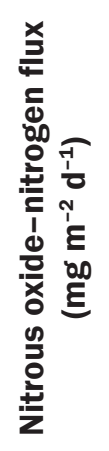

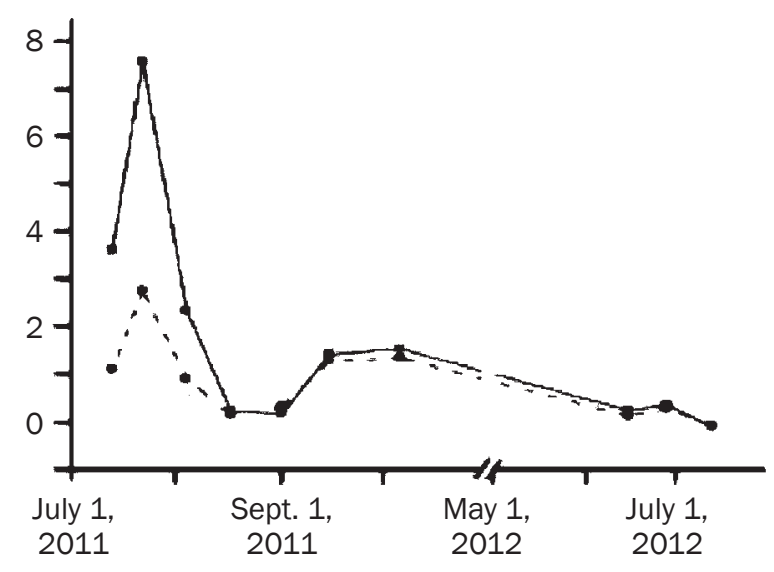

Date sampled

\section{Legend}

$\longrightarrow$ - Corn after corn - - - Corn after soybean

denitrifiers made this treatment combination the most active in emitting $\mathrm{N}_{2} \mathrm{O}$.

Global Warming Potential. The Wooster site had a higher GWP than did the Hoytville site $(p=0.028)$ and the CC rotation had a higher GWP than did the CS rotation ( $p=$ 0.075 ) (table 4 and figure 7). The GWP is mostly a result of $\mathrm{CO}_{2}$ and $\mathrm{N}_{2} \mathrm{O}$ because the soil was actually a sink for $\mathrm{CH}_{4}$. The GWP for Hoytville was lower than the GWP for Wooster probably due to the differences of crop yields. Corn yields during the time this study was conducted tended to be better at Wooster (site average was $13.6 \mathrm{Mg} \mathrm{ha}^{-1}$ [217 $\left.\mathrm{bu}^{-1} \mathrm{ac}\right]$ ) than Hoytville (site average was 11.3 $\left.\mathrm{Mg} \mathrm{ha}^{-1}\left[180 \mathrm{bu}^{-1} \mathrm{ac}\right]\right)$. This would lead to more roots and residues in the fields for decomposition and thus more $\mathrm{CO}_{2}$ emissions from the Wooster site. However, the Wooster soils also received less amounts of $\mathrm{N}$ fertilizer that would lead to a lower GWP. This illustrates that calculating GWP using $\mathrm{CO}_{2}$ as part of the equation is fraught with problems because it tends to dominate the calculation. A large $\mathrm{CO}_{2}$ flux cycle due to cycling of photosynthetically fixed $\mathrm{C}$ without any net $\mathrm{C}$ sequestration in the soil may not really have any net GWP, but can greatly affect calculations of total GWP-at least on the short-term basis. Long-term studies are needed to more accurately incorporate all of the greenhouse gases into a GWP value.

If GWP is calculated using only $\mathrm{N}_{2} \mathrm{O}$ and $\mathrm{CH}_{4}$, the values for the silty clay loam soil Hoytville and silt loam Wooster site are similar. This was because the $\mathrm{N}_{2} \mathrm{O}$ emissions for the two sites were similar and the $\mathrm{CH}_{4}$ fluxes had only a small effect on the GWP calculated for each site.

The significantly larger GWP from CC rotations than CS rotations is due to the larger residue amounts being returned to the soil from the corn stalks than the soybean stalks, and more total fertilizer $\mathrm{N}$ applied in the CC than the CS rotation. It should be noted that there was no significant difference in GWP by tillage treatments in spite of individual gases showing tillage differences. This seems to be caused by large $\mathrm{CO}_{2}$ emissions being countered by smaller $\mathrm{N}_{2} \mathrm{O}$ emissions or vice versa.

\section{Summary and Conclusions}

The NT management system released less $\mathrm{CO}_{2}$ than did $\mathrm{MT}$, and the CS rotation released fewer $\mathrm{CO}_{2}$ emissions than did the $\mathrm{CC}$ rotation at the Wooster site. At the Hoytville 
Table 3

Analysis of variance (ANOVA) for carbon dioxide $\left(\mathrm{CO}_{2}\right)$, methane $\left(\mathrm{CH}_{4}\right)$, and nitrous oxide $\left(\mathrm{N}_{2} \mathrm{O}\right)$ fluxes from the Hoytville site.

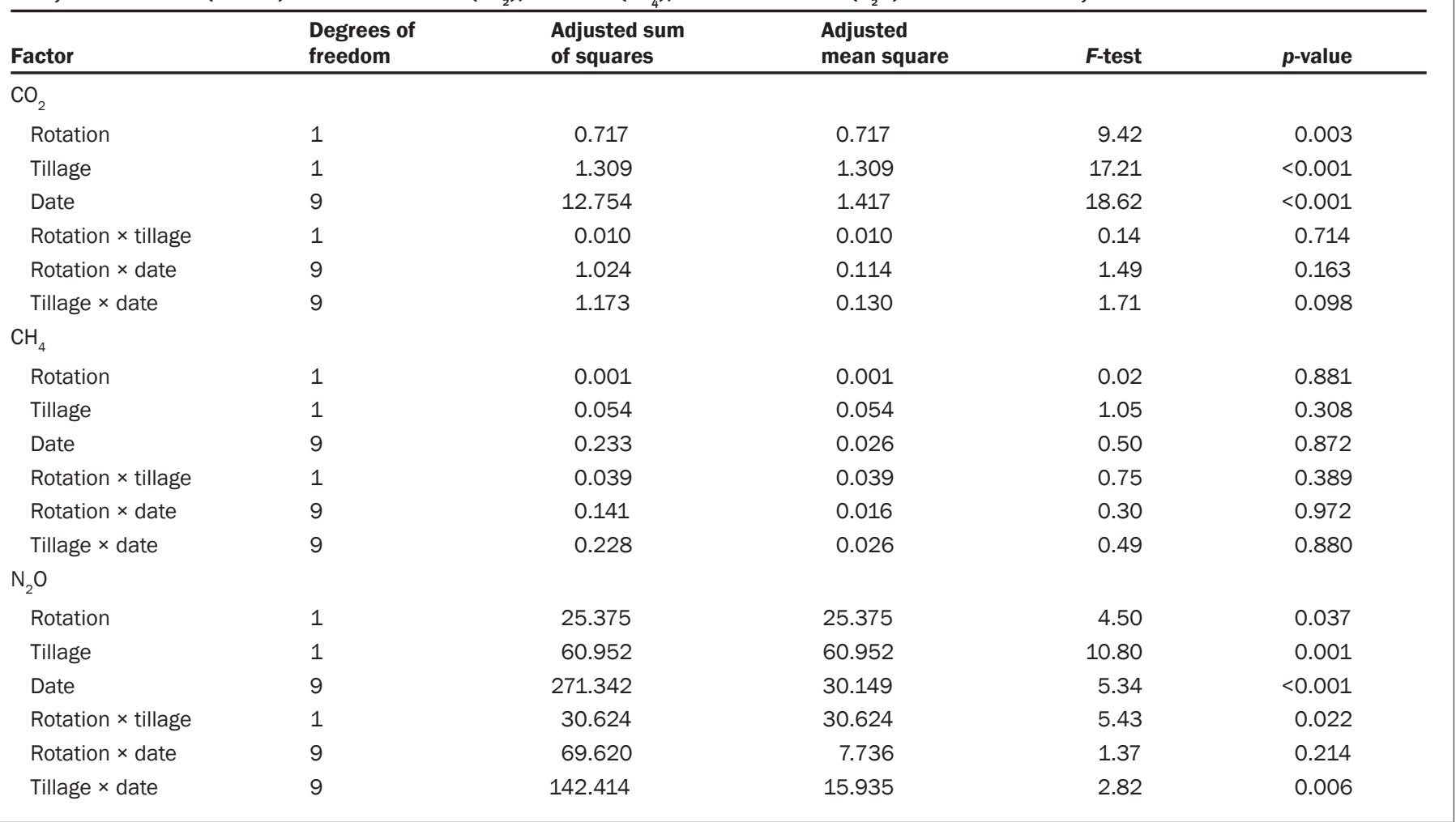

Table 4

Analysis of variance for global warming potential at the Wooster and Hoytville sites.

\begin{tabular}{llccrl}
\hline Factor & $\begin{array}{l}\text { Degrees of } \\
\text { freedom }\end{array}$ & $\begin{array}{l}\text { Adjusted sum } \\
\text { of squares }\end{array}$ & $\begin{array}{l}\text { Adjusted mean } \\
\text { of squares }\end{array}$ & F-test & p-value \\
\hline Site & 1 & 130.433 & 130.433 & 511.18 & 0.028 \\
Tillage & 1 & 0.431 & 0.431 & 1.69 & 0.418 \\
Rotation & 1 & 18.344 & 18.344 & 71.89 & 0.075 \\
Site $\times$ tillage & 1 & 0.215 & 0.215 & 0.84 & 0.527 \\
Tillage $\times$ rotation & 1 & 0.918 & 0.918 & 3.6 & 0.309 \\
Site $\times$ rotation & 1 & 4.284 & 4.284 & 16.79 & 0.152 \\
& & & & &
\end{tabular}

site, $\mathrm{CO}_{2}$ emissions increased under NT due to faster cycling of nutrients while $\mathrm{N}_{2} \mathrm{O}$ increased under MT. The overall emissions were decreased by practicing a crop rotation of CS versus CC. The clay soil of Hoytville had a lower GWP than did the silt loam of Wooster, but also has a recent history of lower yields. Crop rotation led to a lower GWP than monocropping of corn did, which would help to enforce the idea that this management practice is environmentally beneficial. Also, the benefits that have been found for the adoption of NT, when combined with crop rotations, suggest that the simultaneous adoption of both practices will lead to improved crop production and environmental benefits.

\section{Acknowledgements}

This work was supported by a regional collaborative project of the USDA National Institute of Food and Agriculture (NIFA), Award No. 2011-68002-30190, Cropping Systems Coordinated Agricultural Project: Climate Change, Mitigation, and Adaptation in Corn-Based Cropping Systems (project website: sustainablecorn.org), and from state and federal funds appropriate to the Ohio Agricultural Research and Development Center-The Ohio State University (OARDC-OSU).

\section{References}

Adhya, T., P. Pattnaik, S. Satpathy, S. Kumaraswamy, and N. Sethunathan. 1998. Influence of phosphorus application on methane emission and production in flooded paddy soils. Soil Biology Biochemistry 30:177-181.
Alvarez, R., and H.S. Steinbach. 2009. A review of the effects of tillage systems on some soil physical properties, water content, nitrate availability and crops yield in the Argentine Pampas. Soil Till Research 104:1-15.

Bouwman, A. 1996. Direct emission of nitrous oxide from agricultural soils. Nutrient Cycling in Agroecosystems 46:53-70.

Bronson, K., and A. Mosier. 1994. Suppression of methane oxidation in aerobic soil by nitrogen fertilizers, nitrification inhibitors, and urease inhibitors. Biology and Fertility of Soils 17:263-268.

Campbell, B.D. 2012. Carbon budgets and greenhouse gas emissions associated with two long-term tillage and crop rotation sites in Ohio. Masters thesis, The Ohio State University.

Cole, C., J. Duxbury, J. Freney, O. Heinemeyer, K. Minami, A. Mosier, K. Paustian, N. Rosenberg, N. Sampson, and D. Sauerbeck. 1997. Global estimates of potential mitigation of greenhouse gas emissions by agriculture. Nutrient Cycling in Agroecosystem 49:221-228.

Dick, W.A, E. McCoy, W. Edwards, and R. Lal. 1991. Continuous application of no-tillage to Ohio soils. Agronomy 83:65-73.

Dick, W.A., D. Van Doren Jr., G. Triplett Jr., and J. Henry. 1986a. Influence of long-term tillage and rotation combinations on crop yields and selected soil parameters. Results obtained for a Mollic Ochraqualf soil. Wooster, OH: The Ohio State University and The Ohio Agricultural Research and Development Center. Research Bulletin 1180. 


\section{Figure 5}

Greenhouse gas fluxes as affected by tillage from the Hoytville site. The * shows a difference between chisel tillage and no-tillage at $p \leq 0.10$ at specific sample dates.

(a)

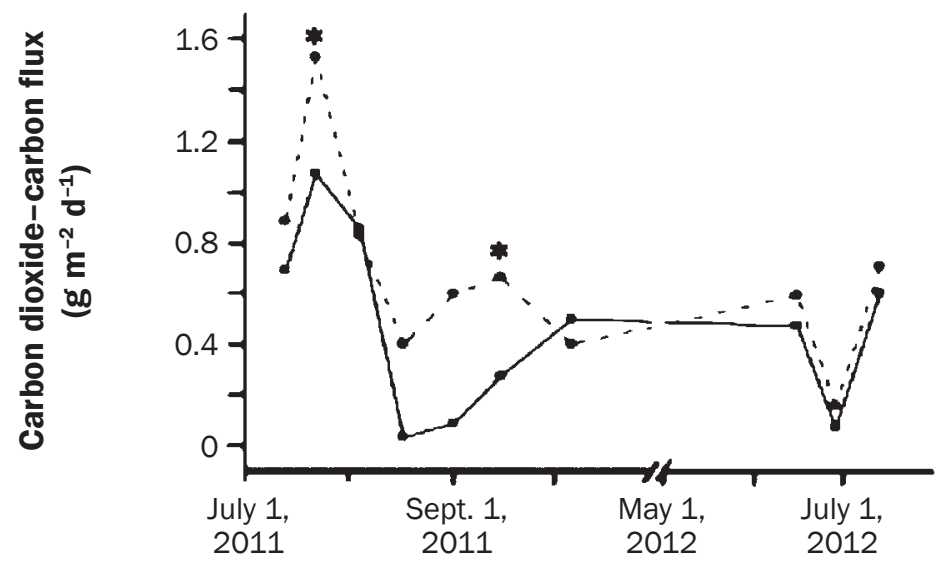

Date sampled

(b)

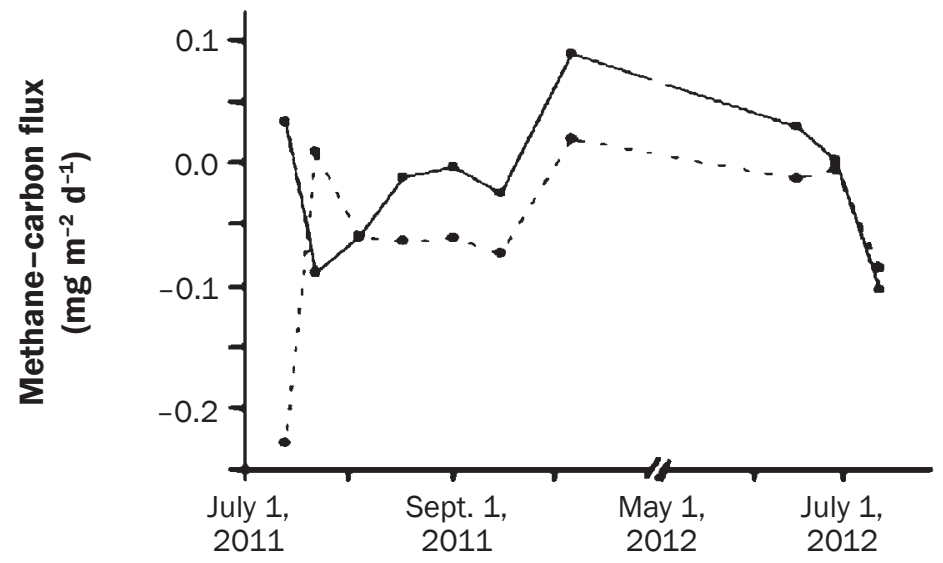

Date sampled

(c)

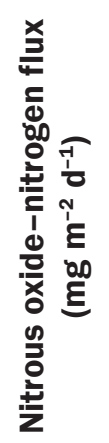

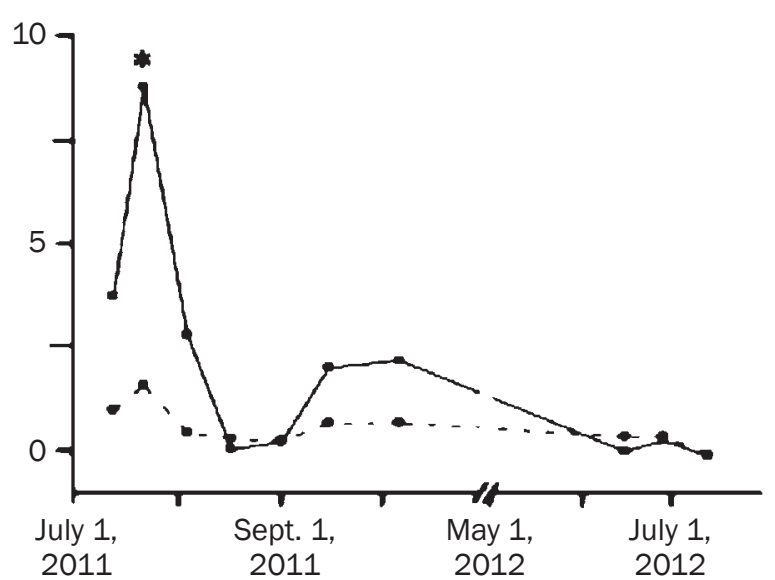

Date sampled

\section{Legend}

- Chisel or minimum conservation tillage $\quad-$ - No-tillage

Dick, W.A., D. Van Doren Jr, G. Triplett Jr., and J. Henry. 1986b. Influence of long-term tillage and rotation combinations on crop yields and selected soil parameters. II. Results obtained for a Typic Fragiudalf soil. Wooster, Ohio: The Ohio State University and The Ohio Agricultural Research and Development Center. Research Bulletin 1181

Flessa, H., R. Ruser, P. Dörsch, T. Kamp, M. Jimenez, J. Munch, and F. Beese. 2002. Integrated evaluation of greenhouse gas emissions $\left(\mathrm{CO}_{2}, \mathrm{CH}_{4}, \mathrm{~N}_{2} \mathrm{O}\right)$ from two farming systems in southern Germany. Agric. Ecosyst. Environ. 91:175-189.

Grant, B., W.N. Smith, R. Desjardins, R. Lemke, and C. Li. 2004. Estimated $\mathrm{N}_{2} \mathrm{O}$ and $\mathrm{CO}_{2}$ emissions as influenced by agricultural practices in Canada. Climate Change 65:315-332.

Halvorson, A.D., A.R. Mosier, C.A. Reule, and W.C. Bausch. 2006. Nitrogen and tillage effects on irrigated continuous corn yields. Agronomy 98:63-71.

Huang, Y., Y. Jian, L. Zong, Y. Wang, and R.L. Sass. 2002. Nitrous oxide emissions from the wheat-growing season in eighteen Chinese paddy soils: An outdoor pot experiment. Biology and Fertility of Soils 36:411-417.

Hsu, Y., S.K. Singh, M. Chiang, Y. Wu, and I. Chang. 2010. Strategies to lower greenhouse gas level by rice agriculture. African Journal of Biotechnology 8:126-132.

Ishizuka, S., A. Iswandi, Y. Nakajima, S. Yonemura, S. Sudo, H. Tsuruta, and D. Murdiyarso. 2005. The variation of greenhouse gas emissions from soils of various landuse/cover types in Jambi province, Indonesia. Nutrient Cycling of Agroecosystems 71:17-32

Jacinthe, P.A., and W.A. Dick. 1997. Soil management and nitrous oxide emissions from cultivated fields in southern Ohio. Soil Tillage Research. 41:221-235.

Jacinthe, P.A., W.A. Dick, R. Lal, R.K. Shrestha, and S. Bilen. 2014. Effects of no-till duration on methane oxidation capacity of Alfisols. Biology of Fertility of Soils (in press).

Jarecki, M.K., T.B. Parkin, A.S.K. Chan, J.L. Hatfield, and R. Jones. 2008. Greenhouse gas emissions from two soils receiving nitrogen fertilizer and swine manure slurry. Environmental Quality 37:1432:1438.

Koga, N., T. Sawamoto, and H. Tsuruta. 2006. Life cycle inventory-based analysis of greenhouse gas emissions from arable land farming systems in Hokkaido, northern Japan. Soil Science Plant Nutrition 52:564-574.

Konyar, K. 2001. Assessing the role of US agriculture in reducing greenhouse gas emissions and generating additional environmental benefits. Ecology Economics 38:85-103.

Kumar, S., A. Kadono, R. Lal and W. Dick. 2012. Long-term no-till impacts on organic carbon and properties of two contrasting soils and corn yields in Ohio. Soil Science Society of America 76:1798-1809. 


\section{Figure 6}

Significant interaction $(p \leq 0.10)$ of crop rotation and tillage for averaged daily nitrous oxidenitrogen $\left(\mathrm{N}_{2} \mathrm{O}-\mathrm{N}\right)$ emissions from the Hoytville site during the sampling period of this study.

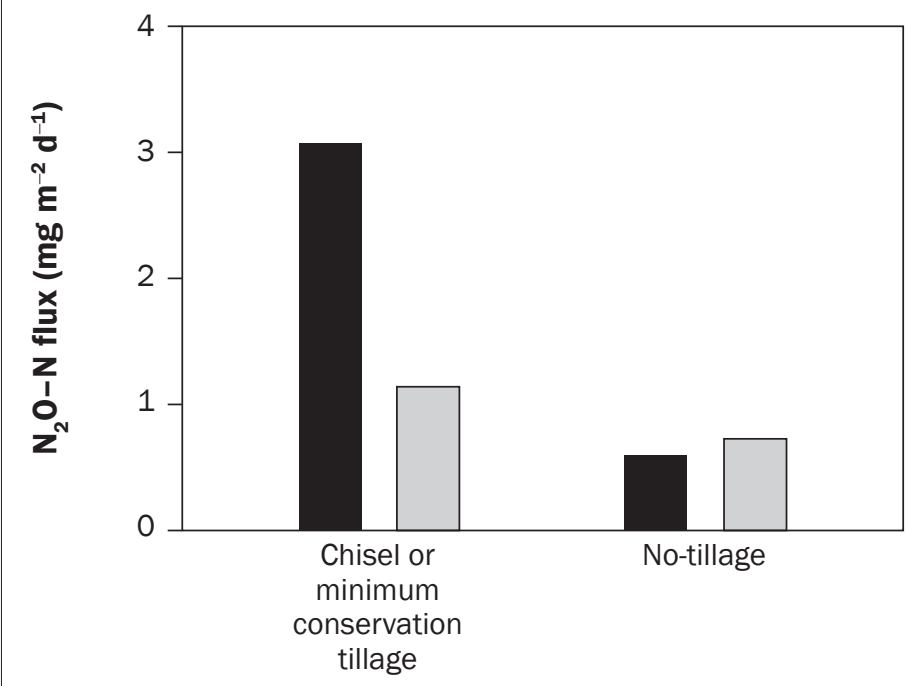

Tillage

\section{Legend}

Corn after corn

Corn after soybean

\section{Figure 7}

Global warming potential based on converting carbon dioxide $\left(\mathrm{CO}_{2}\right)$, methane $\left(\mathrm{CH}_{4}\right)$, and nitrous oxide $\left(\mathrm{N}_{2} \mathrm{O}\right)$ to $\mathrm{CO}_{2}-\mathrm{C}$ equivalents as affected by site and crop rotation. Different letters over each bar in the same group (different crop rotations or different experimental sites) represent a significant difference at $p \leq 0.10$.

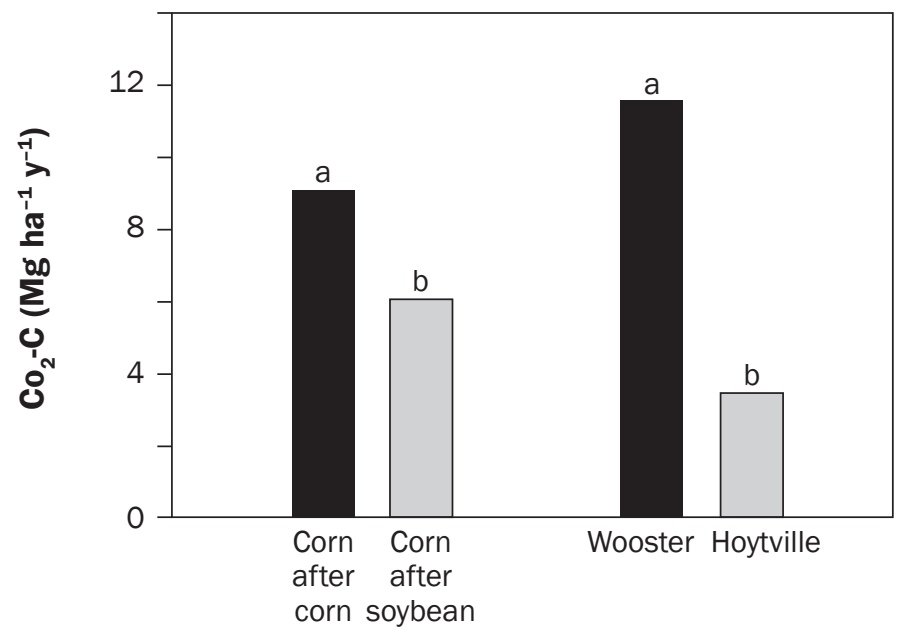

\section{Site}

Lal, R. 1997. Residue management, conservation tillage and soil restoration for mitigating greenhouse effect by $\mathrm{CO}_{2}$-enrichment. Soil Tillage Research 43:81-107.

MacKenzie, A., M. Fan, and F. Cadrin. 1997. Nitrous oxide emission as affected by tillage, corn-soybean-alfalfa rotations and nitrogen fertilization. Canadian Journal of Soil Science 77:145-152.

Molodovskaya, M., O. Singurindy, B.K. Richards, J. Warland, M.S. Johnson, and T.S. Steenhuis. 2012. Temporal variability of nitrous oxide from fertilized croplands: Hot moment analysis. Soil Science Society of America 76:1728-1740.

Omonode, R.A., D.R. Smith,A. Gál, and T.J.Vyn. 2011 Soil nitrous oxide emissions in corn following three decades of tillage and rotation treatments. Soil Science Society of America 75:152-163.

Pant, K.P. 2009. Effects of agriculture on climate change: A cross country study of factors affecting carbon emissions. Agriculture and Environment10:84-102.

Parkin, T.B., and T.C. Kaspar. 2006. Nitrous oxide emissions from corn/soybean systems in the Midwest. Environmental Quality 35:1496-1506.

Parry, M.L., O.F. Canziani, J.P. Palutikof, P.J. van der Linden, and C.E. Hanson. 2007. Climate change 2007: Impacts, adaptation and vulnerability. Contribution of Working Group II to the Fourth Assessment Report of the Intergovernmental Panel on Climate Change. Cambridge, UK: Cambridge University Press.

USEPA (US Environmental Protection Agency). 2006. Global mitigation of non- $\mathrm{CO}_{2}$ greenhouse gases. Rep. 430-R-06-005. Washington, DC: United States Environmental Protection Agency, Office of the Atmospheric Programs (6207J).

Venterea, R.T., M. Burger, and K.A. Spokas. 2005. Nitrogen oxide and methane emissions under varying tillage and fertilizer management. Environmental Quality 34:1467-1477.

Weitz, A.M., E. Linder, S. Frolking, P.M. Crill, and M. Keller. 2001. $\mathrm{N}_{2} \mathrm{O}$ emissions from humid tropical agricultural soils: Effects of soil moisture, texture and nitrogen availability. Soil Biology Biochemistry 33:1077-1093. 